\title{
Biological parameters of Bonylip barb (Osteochilus vittatus Valenciennes, 1842) in Lake Rawa Pening Semarang Regency
}

\author{
[Parameter biologis ikan nilem (Osteochilus vittatus Valenciennes, 1842) \\ di Danau Rawa Pening Kabupaten Semarang] \\ Sadza Maulidyasari \& Djumanto ${ }^{\bowtie}$ \\ Laboratorium Manajemen Sumberdaya Perikanan \\ Jurusan Perikanan, Fakultas Pertanian Universitas Gadjah Mada. \\ Jalan Flora Gedung A4, Bulaksumur Yogyakarta 55281 \\ lely4192@yahoo.com
}

Diterima: 21 Mei 2020; Disetujui: 15 September 2020

\begin{abstract}
Bonylip barb (Osteochilus vittatus Valenciennes, 1842) is an indigenous fish which is the main target of fishermen in lake Rawa Pening. This study aims to determine the biological parameters including length-weight relationship, condition factor, and sex ratio of bonylip barb in lake Rawa Pening, Semarang Regency. Fish sampling was conducted biweekly from October 2019 to March 2020, caught using bamboo blinds operated by local fishermen. Data collected consisted of total length, individual weight, and sex. Data on the length-weight relationship and condition factors were analyzed descriptively, while the sex ratio was analyzed with the chi-square test $\left(\chi^{2}\right)$. The results showed that female bonylip barb was obtained as many as 392 individuals with a length-range between $10.0-26.0 \mathrm{~cm}$ and a weight range between 14.5-264.1 g. The male counted 255 individuals with a length range of 10.2-22.4 cm and a weight range of 15.0-160.9 g. The growth pattern was allometric negative. The equation of the length-weight relationship of female was $\mathrm{W}=0.0186 \mathrm{~L}^{2.9096}\left(\mathrm{R}^{2}=0.9527\right)$, and the male was $\mathrm{W}=0.0151 \mathrm{~L}^{2.9689}\left(\mathrm{R}^{2}=0.9386\right)$. The value of the average condition factor of females was 1.05, and the males was 1.02. The condition factor in females was in excellent condition (> 1.05), and males were in good condition (0.95-1.05). The overall sex ratio of male and female was 1:1.54. It means that females population was significantly higher than males.
\end{abstract}

Keywords: bonylip barb, growth, lake, sex ratio

\begin{abstract}
Abstrak
Ikan nilem (Osteochilus vittatus Valenciennes, 1842) merupakan ikan asli yang menjadi target utama tangkapan nelayan di Rawa Pening. Penelitian ini bertujuan untuk mengetahui parameter biologi yang meliputi hubungan panjangberat, faktor kondisi dan nisbah kelamin ikan nilem di danau Rawa Pening Kabupaten Semarang. Pengambilan sampel ikan dilakukan dua minggu sekali dari bulan Oktober 2019 sampai Maret 2020, menggunakan kerai bambu yang dioperasikan oleh nelayan setempat. Data yang dikumpulkan terdiri atas panjang total, bobot individu, dan jenis kelamin. Data hubungan panjang-berat dan faktor kondisi dianalisis secara deskriptif, sedangkan nisbah kelamin dianalisis dengan uji chi-square $\left(\chi^{2}\right)$. Hasil penelitian diperoleh jumlah ikan nilem betina sebanyak 392 ekor dengan kisaran panjang antara 10,0-26,0 cm dan kisaran berat antara 14,5-264,1 g. Ikan nilem jantan sebanyak 255 ekor dengan kisaran panjang antara 10,2-22,4 cm dan kisaran berat antara 15,0-160,9 g. Pola pertumbuhan ikan nilem di danau Rawa Pening bersifat allometri negatif. Persamaan hubungan panjang-berat ikan nilem betina yaitu $\mathrm{W}=0.0186 \mathrm{~L}^{2.9096}\left(\mathrm{R}^{2}=\right.$ $0.9527)$, dan jantan yaitu $\mathrm{W}=0.0151 \mathrm{~L}^{2.9689}\left(\mathrm{R}^{2}=0.9386\right)$. Nilai faktor kondisi ikan nilem betina rerata 1,05 , sedangkan ikan nilem jantan rerata 1,02. Proporsi faktor kondisi ikan nilem betina terbanyak dalam keadaan sangat baik $(>1,05)$, sedangkan ikan nilem jantan berada dalam kondisi baik $(0,95-1,05)$. Rasio betina dan jantan secara keseluruhan yaitu $1,54: 1$, yang menunjukkan populasi betina secara nyata lebih banyak dari pada jantan.
\end{abstract}

Kata kunci: danau, nilem, nisbah kelamin, pertumbuhan

\section{Introduction}

Lake Rawa Pening is formed through the damming of the Tuntang River so that it has an elongated oval shape. It's located in Central Java Province and is bordered by four districts, namely Bawen, Banyubiru, Ambarawa and Tuntang. It's surrounded by hills, mountains, and dams in Tuntang river (Aida \& Utomo 2016). Lake Rawa Pening has an area of around 17702770 hectares, a depth of 1.5-2.5 m, and a volume of water around 25-65 million $\mathrm{m}^{3}$. Water entering lake Rawa Pening carries nutrients from upstream that can increase water fertility so that lake Rawa Pening has great fishery potential for 
the surrounding community (Samudra et al. 2013).

Lake Rawa Pening is a freshwater ecosystem in Central Java Province that has a large potential of fishery resources. Fishery activities in lake Rawa Pening consist of capture fisheries and aquaculture that aim to improve the community's economy. Fishing in lake Rawa Pening is done using various types of fishing gear such as lift net, bamboo blinds, fishing rods, gill nets, fishing trap, and nets. The fish capture consists of red devil (Amphilophus amarillo), Indonesian snakehead (Channa micropeltes), striped snakehead (Channa striata), Bronze featherback (Notopterus notopterus), Mozambique tilapia (Oreochromis mossambicus), Nile tilapia (Oreochromis niloticus), bonylip barb (Osteochillus vitattus), Marble goby (Oxyeleotris marmorata), Yellow rasbora (Rasbora lateristriata) and Three spot gourami (Trichopodus trichopterus) (Weri \& Sucahyo 2017). Fish catch production in lake Rawa Pening is 1,000-1,200 tons/year (Aida \& Utomo 2016).

The main commodity of fish capture in lake Rawa Pening is bonylip barb. It's an endemic fish in lake Rawa Pening whose presence has gradually declined. Previously this species was known as Osteochillus hasseltii and then changed to Osteochillus vitattus (Froese \& Pauly 2019). Bonylip barb is exploited for fresh consumption of the community, which is distributed to the surrounding cities. The level of exploitation carried out is very high and continuous without management, resulting in overfishing that can threaten sustainability.

Analysis of the length-weight relation-nship is very useful for estimating the average value of fish caught from a sample of the fish's length. Length-weight relationships can provide information on fish species' growth patterns and conditions (Radhi et al. 2018). Information on the length and weight relationship of a fish species can be used to estimate the weight or size of a particular fish species and determine the fishing gear's selectivity. Likewise, the sex ratio can be used to determine the reproductive potential of fish in the water. The condition factor is a value that indicates the plumpness or thinness of the fish. Research on the biological parameters of the bonylip barb in lake Rawa Pening has done by Rochmatin et al. (2016) in short periods, so it needs to be done to add data and information about the biological aspects. The study of length and weight is significant for fisheries studies, conservation, and fish management in aquatic systems. Information on the length-weight relationship, the condition factor, and the sex ratio is expected to provide information on the biological aspect of the bonylip barb in lake Rawa Pening. It can be the basis for fisheries management and the development of further research on aspects of fisheries biology, especially related to the growth of bonylip barb in lake Rawa Pening. This study aims to determine the biological parameters that include length-weight relationship, the condition, and the sex ratio of bonylip barb fish in the lake Rawa Pening Semarang Regency.

\section{Material and method}

\section{Sampling station}

The bonylip barb sampling was carried out at six sampling stations in lake Rawa Pening (Figure 1). The fish was collected using several sheets of bamboo blinds with a length of $20 \mathrm{~m} \mathrm{x}$ $2 \mathrm{~m}$ and a gap width of $1 \mathrm{~cm}$. Fish hiding under hordes of water hyacinth plants were locked up using bamboo blinds. The fence size was reduced 


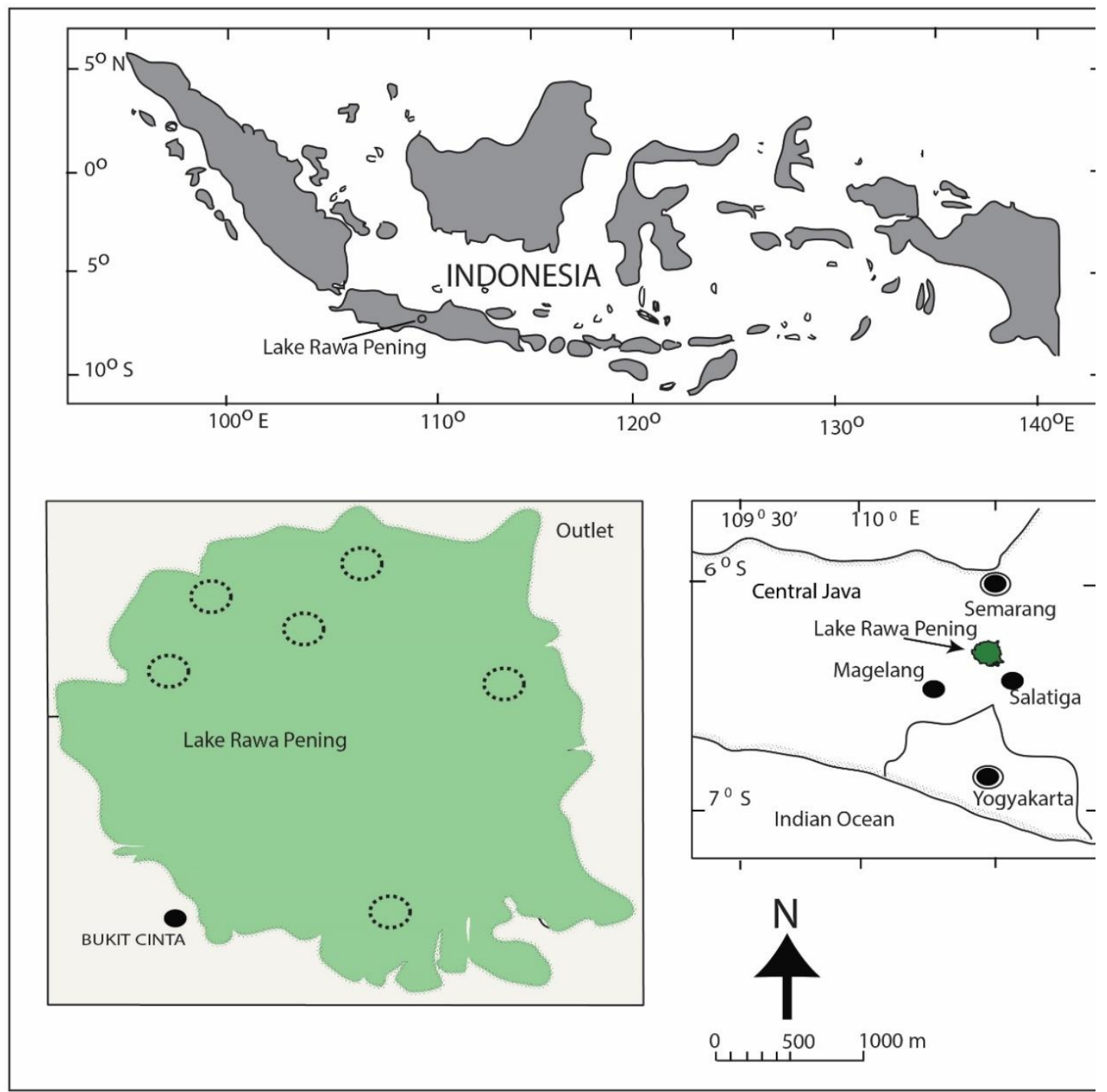

Figure 1 Map of lake Rawa Pening where bonylip barb was sampled using a blind bamboo fence on a hyacinth group (circle dash line).

gradually by sliding the blinds toward the center, and the water hyacinth plants were removed. When the size of the cage gets smaller, then the trapped fish were collected using a net. Sampling was conducted biweekly from October 2019 to March 2020. Fish collected every month about 100 individuals.

Bonylip barb captured was keep in a cool box that was given ice cubes to maintain freshness. Fish samples were then transferred to the Aquatic Resources Management Laboratory to measure the total length, individual weight, and sex identification. Female fish have gonads while males have testes in their abdominal cavity.

Each fish was measured the total length from the tip of the upper jaw to the tip of the tail fin using a ruler with an accuracy of $0.1 \mathrm{~cm}$. Fish weights were measured using a digital scale with a precision of $0.1 \mathrm{~g}$. Each fish is then dissected to the abdomen to determine its sex. 


\section{Data analysis}

The sex ratio of females and males was tested using chi-square $\left(\chi^{2}\right)$, with the following formula (Effendie 1979, Biswas 1993).

$$
\chi^{2}=\sum_{i=1}^{k} \frac{(o i-e i)^{2}}{e i}
$$

Note: $\chi^{2}=$ sex distribution ratio, oi $=$ observation frequency, ei $=$ expectation frequency

The length and weight parameters of the fish were used to estimate the fish length-weight relationship model. Furthermore, by using a fish length-weight relationship model, fish growth patterns could be determined. The long-term relationship model was obtained through correlation analysis and linear regression using the following equation (Effendie 1979, Biswas 1993):

$$
\mathrm{W}=\mathrm{aL}^{\mathrm{b}}
$$

where: $\mathrm{W}=$ weight of individual fish $(\mathrm{g}), \mathrm{a}=$ intercept, $\mathrm{L}=$ total length of fish $(\mathrm{cm}), \mathrm{b}=$ slope

The formula of the power equation was then differentiated to a linear equation $\mathrm{y}=\mathrm{a}+\mathrm{bx}$ with logarithms, so that it becomes $\log \mathrm{W}=\log \mathrm{a}+\mathrm{b}$ $\log \mathrm{L}$. Note: $\mathrm{y}=\log \mathrm{W}, \mathrm{a}=\log \mathrm{a}$, and $\mathrm{x}=\log \mathrm{L}$. The $b$ value was the slope, and the a value was the intersection point with the $y$-axis. Then the $t$ test of the value of $b$ was performed to find out the real difference with 3 . If $b=3$, then the fish growth pattern was isometric, whereas if $b \neq 3$, then the allometric fish growth pattern. Fish growth patterns were then used to determine the condition factor of the fish.

Fish condition factors $\left(\mathrm{K}_{\mathrm{TL}}\right)$ on isometric growth were calculated by formula according to Biswas (1993), that was:

$$
\mathrm{K}_{\mathrm{TL}}=\frac{10^{5} \mathrm{w}}{1^{3}}
$$

where $\mathrm{w}=$ body weight $(\mathrm{g}), \mathrm{l}=$ length $(\mathrm{mm})$

In allometric conditions, the relative condition factor $\left(\mathrm{K}_{\mathrm{n}}\right)$ of fish was calculated by the following formula:

$$
\mathrm{K}_{\mathrm{n}=} \frac{\mathrm{w}}{\mathrm{al}^{\mathrm{b}}}
$$

\section{Results}

Sex ratio

The ratio between females and males as a whole was 1.54: 1 . The overall female population was more abundant than male populations. The ratio of female and male every month is presented in Table 1.

The sex ratio of the bonylip barb as a whole has more female populations than males. Similarly, the female population at the beginning of the rainy season (October-December) is more than the peak rainy season (JanuaryFebruary). Equal male and female populations occur at the peak rainy season. The sex ratio based on the length, which is $<14 \mathrm{~cm}$ long, between $14-18 \mathrm{~cm}$ and $>18 \mathrm{~cm}$, shows that at a length of 14-18 cm the population of females and

Table 1 Female and male sex ratios of bonylip barb monthly sampling in Lake Rawa Pening

\begin{tabular}{llllllll}
\hline Sex & Oct & Nov & Dec & Jan & Feb & Mar & Total \\
\hline+ & 74 & 57 & 61 & 55 & 65 & 80 & 392 \\
0 & 19 & 28 & 37 & 68 & 56 & 47 & 255 \\
Total & 93 & 85 & 98 & 123 & 121 & 127 & 647 \\
Ratio & 3.89 & 2.04 & 1.65 & 0.81 & 1.16 & 1.70 & 1.54 \\
$\chi$ count & $32.53^{*}$ & $9.89^{*}$ & $5.88^{*}$ & 1.37 & 0.67 & $8.57^{*}$ & $29.01^{*}$ \\
$\chi$ table & 3.84 & 3.84 & 3.84 & 3.84 & 3.84 & 3.84 & 3.84 \\
\hline
\end{tabular}

Sign $*$ shows significantly different $(\mathrm{P}>0.05)$ 
males was balanced, while the sizes of $<14 \mathrm{~cm}$ and $>18 \mathrm{~cm}$ females were more numerous.

\section{Distribution of length and weight}

The size distribution frequency of females and males is presented in Figure 2. The number of bonylip barb samples obtained was 647 individuals, with the composition of female 392 individuals and males 255 individuals. Overall total length ranges from $10.0-26.0 \mathrm{~cm}$. The size of females ranges from 10.0-26.0 cm. Meanwhile, males range from $10.0-23.0 \mathrm{~cm}$. The length distribution of females and males was relatively similar.

The length frequency of females has two modes at sizes 14 and $18 \mathrm{~cm}$, whereas males have one mode at a size of $15 \mathrm{~cm}$, respectively. The length distribution for females was do-minated ( $>$ $10 \%$ ) size of $18-20 \mathrm{~cm}$, whereas the size of $14-18$ $\mathrm{cm}$ dominated the male. The average female was $16.8 \mathrm{~cm}$, whereas, in females, it was $15.4 \mathrm{~cm}$.

As a whole, the individual weight of bonylip barb ranges from 14.5-264.0 g. The weight of individuals female ranged from 14.5-264.0 g,

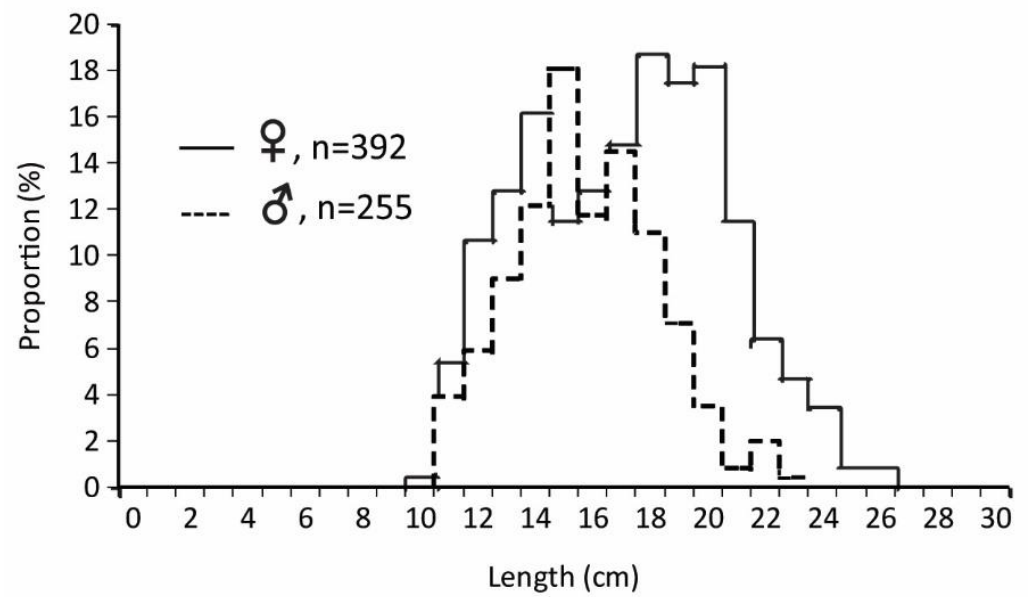

Figure 2 The total length frequency distribution of female (-) and male (----) bonylip barb in lake Rawa Pening.

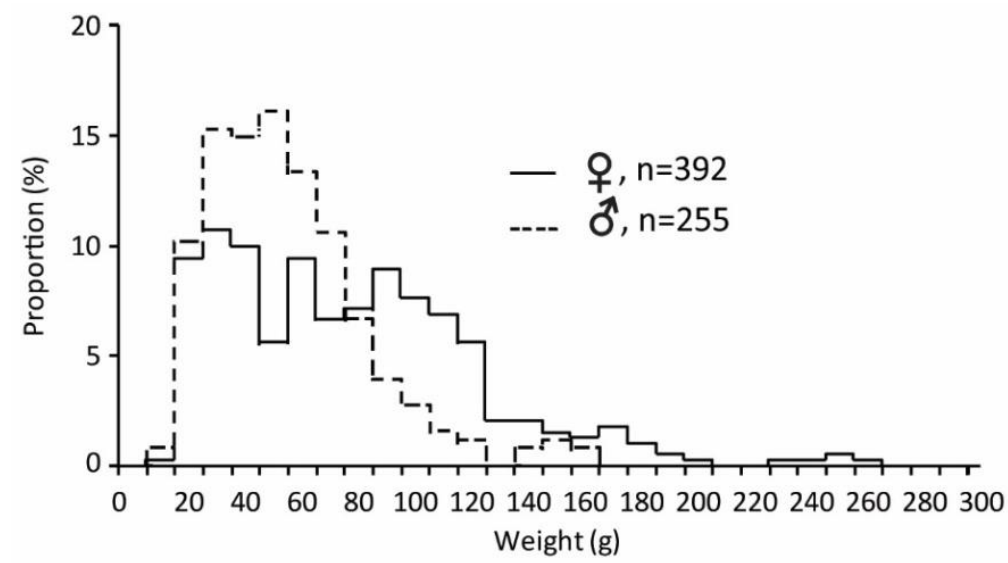

Figure 3 Distribution of weight of individual females (-) and males (----) of bonylip barb in lake Rawa Pening 


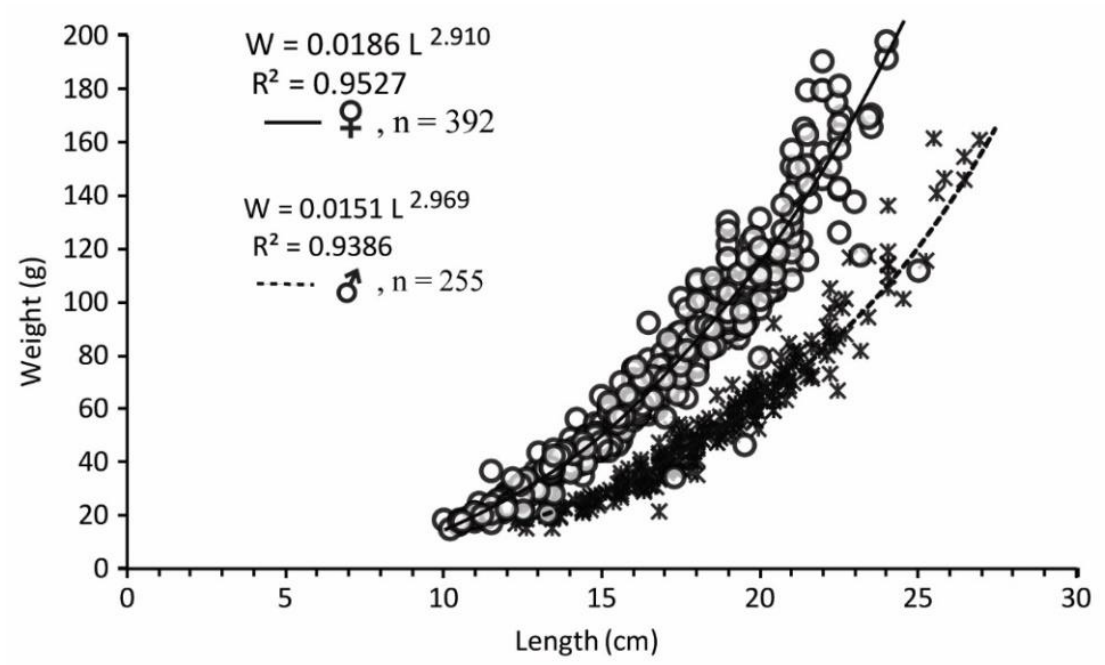

Figure 4 Length-weight relationship of female (-) and male (----) bonylip barb in lake Rawa Pening.

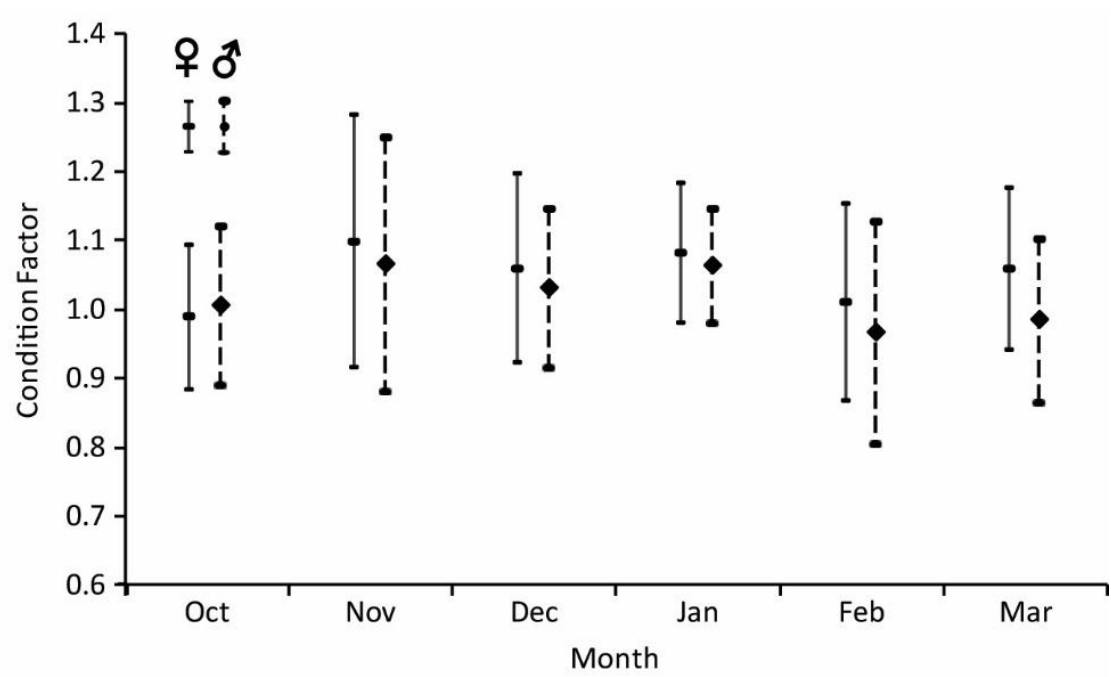

Figure 5 Condition factors (mean and standard deviation) of female (-) and male (- - - -) bonylip barb in lake Rawa Pening.

whereas in males ranges from 15.0-161.0 g. The distribution of the individual weight of males and females is presented in Figure 3.

Overall, the individual weight ranges between 15-260 g. Females have a broader range of sizes, with four size groups, namely $<50,50$ $120,120-200$, and $>200 \mathrm{~g}$, while the male distribution was narrower with two groups, namely $<100$ and $>100 \mathrm{~g}$ of size groups. The individual weight of females ranges between 15 -
$260 \mathrm{~g}$, whereas in males ranges between 15-160 g. The individual weights of the female were dominated between 20-120 g, while the male ranged from 20-80 g.

The length and weight relationships are presented in Figure 4. The length-weight relationship in the female population determined the equation $\mathrm{W}=0.0186 \mathrm{~L}^{2.910}$ with a coefficient of determination $\left(\mathrm{R}^{2}\right)$ of 0.9527 . In the male population, the length-weight relationship equation 


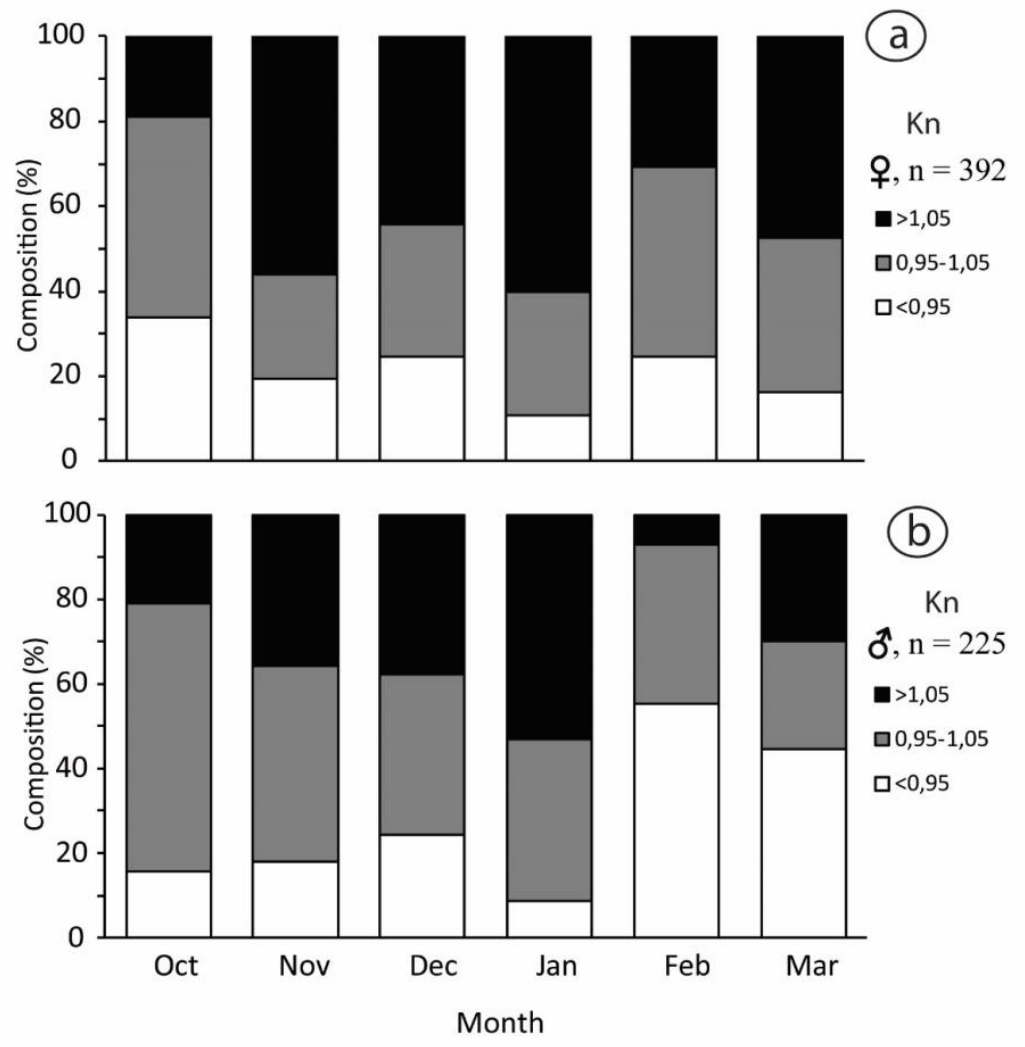

Figure 6. The proportion of female (a) and male (b) bonylip barb in lake Rawa Pening.

was $\mathrm{W}=0.0186 \mathrm{~L}^{2.969}$, with a coefficient of determination $\left(\mathrm{R}^{2}\right)$ of 0.9386 . The value of $\mathrm{b}$ in the female population was 2.910 , and the male was 2.969. The results of the statistical analysis of female and male $b$ values showed $b<3$ so that the growth pattern was negative allometric. The correlation coefficient value in the female population was 0.97 , while the male was 0.98 .

\section{Condition factor}

The condition factors $(\mathrm{Kn})$ of females and males were presented in Figure 5. The condition factor for females ranges from 0.46-1.66 with a mean of 1.05 and a standard deviation of 0.13 . In males, the condition factor ranges between 0.56-2.06 with an average of 1.02 and a standard deviation of 0.13 .

The condition factor value shows the condition level of fish caught in the lake Rawa
Pening. The condition level of bonylip barb classified into three categories, namely the category as thin fish $<0.95$, type as moderate fish 0.95-1.05, and classified as fat fish $>1.05$. Based on the average condition factor of the fish showed moderate obesity. The proportion of condition factor categories is presented in Figure 6.

Female bonylip barb was dominated by category $\mathrm{Kn}>1.05$, which shows the condition of females classified as fat. Females were classified as thin were found in October, while females in the fat category were found in January. The male condition factor was dominated by the group of 0.95-1.05, which indicates moderate obesity. Male in the thin category $(\mathrm{Kn}<0.95)$ were found in February, while the fat group $(\mathrm{Kn}>1.05)$ was found in January. 


\section{Discussion}

In general, the female bonylip barb populations were more numerous and dominant, while male populations were in balance during the peak of the rainy season and in the adult or parent groups. Female groups dominate the fish population in the juvenile and old stage. The bonylip barb females in Sidenreng Lake was also more than the male (Omar 2010). More females were indicators of healthy environmental conditions and abundant feed availability (Famoofo \& Abdul 2020). This result was in contrast to bonylip barb, Osteochilus waandersii in the Landak River that found a higher male population (Soetignya et al. 2020). When the feed condition is limited, competition occurs to obtain feed resources, and a male population with a larger body size will be superior (Rostika et al. 2017). The waters of Lake Rawa Pening were very fertile, providing plankton and aquatic plants, so that female populations were more abundant (Famoofo \& Abdul 2020).

Bonylip barb catches using the bamboo blinds fence at lake Rawa Pening have wide variations in length and weight. The frequency distribution of the total length and individual weight of females spreads wider. Females have more modes and wider length distribution. The female population consists of various groups, namely young $(<12 \mathrm{~cm})$, adult $(12-20)$, and old $(>20 \mathrm{~cm}$ ) (Putri et al. 2015). In the male population, stage groups were found from young until adult, while the elderly population was absent. These results were supported by Rochmatin et al. (2014) using fish samples from the lift net catch. The wide range of length and weight and the many age groups indicate that the Rawa Pening Lake aquatic ecosystem can provide adequate food for all age groups. Lake Rawa Pening is very fertile and classified as eutrophic to hypereutrophic waters (Zulfia \& Aisyah 2013).

The bonylip barb growth was affected by the availability of adequate food and suitable abiotic conditions. The main food types consist of algae and aquatic plants (93\%), then phytoplankton (2.91\%), zooplankton (0.004\%), mollusks $(0.68 \%)$, insects $(0.0005 \%)$, and detritus $(0.21 \%)$ and not identified (Putri et al. 2015). Plankton species were found as many as 147 genera of organisms dominated by the Cryptophyceae, Dinophyceae, Cyanophyceae, Euglenophyceae, and Bacillariophyceae. Several phytoplankton species were very abundant, namely Navicula sp., Peridinium sp., Haematococcus sp., Aulacoseira sp., Synendra sp., and Nitzschia sp. Phytoplankton abundance ranged from 14-20 individuals/l. The density of phytoplankton was higher in the middle of the waters, while low was at the outlet (Samudra et al. 2013). Aquatic plants are dominated by water hyacinth (Eichhornia crassipes) whose cover reaches 20 percent of the surface area. The fresh biomass weight reached $15-28 \mathrm{~kg} / \mathrm{m}^{2}$, and its density was 40-60 individual plants $/ \mathrm{m}^{2}$, with plant height up to $50 \mathrm{~cm}$. Some aquatic plants grew abundantly and became the leading food of bonylip barb, such as Hydrilla verticillata, Salvinia cucculata, and Salvinia molesta (Goeltenboth \& Kristyanto 1994). The abundant feed availability was a significant contributor to the bonylip barb biomass growth in lake Rawa Pening.

Eutrophication in lake Rawa Pening waters was due to organic material's entry through surface streams and spring. The total concentrations of phosphorus, total nitrogen, and chlorophyll-a are very high. The range of nitrate, phosphate, and chlorophyll-a values range from $1.38-2.18 \mathrm{mg} / \mathrm{l}, 0.013-0.030 \mathrm{mg} / \mathrm{l}$, and 4.71- 
$7.30 \mathrm{mg} / \mathrm{l}$ (Zulfia \& Aisyah 2013). The excessive and even uncontrolled growth of algae, plankton, and aquatic plants affected by very high nutrient concentrations. Organic matter entering the waters continues to increase caused a very high concentration of total phosphorus. Phosphorus content in a stream affects the abundance of phytoplankton, affecting food availability for bonylip barb growth.

The length-weight relationship showed negative allometric growth patterns. Increased weight was not as fast as long cubic growth, and fish growth tends to be lean. In general, the value of $b$ ranges from 2.5 to 3.5 (Froese 2006). The fish phase in its life cycle strongly influences the value of $b$, and fish tend to plump when approaching spawning. In this study, the allometric growth pattern was supported by Rochmatin et al. (2013). However, its relatively different from the work of Hamid et al. (2015). They found isometric growth patterns $(b=3.038)$ on bonylip barb in Temengor lake, Malaysia. The difference in the value of $b$ can be due to environmental conditions where fish live, feed availability, fish life phase, fish activity, fish morphometry, sampling time, and several other factors (Famoofo \& Abdul 2020).

Values of $b$ obtained in the same species may differ due to several factors, namely sampling time, habitat differences, ecological conditions, biological conditions, and feed abundance (Radhi et al. 2018). Environmental factors that affect growth patterns such as seasonality and water quality. Changes in the season between rain and drought will affect water quality (Zulfia \& Aisyah 2013). In the rainy season, water sources are very abundant and good quality, so the value of $b$ tends to increase. The biological factors were such as growth phase, sexual maturity, feeding habits. Besides, internal and external factors can affect the growth rate of fish length and weight. Internal factors include genes, sex, age, and disease presence, while external factors include temperature, food availability, and environmental quality. Seasonal changes affect water sufficiency and ecological conditions, so the value of $b$ in the dry season tends to decrease (Famoofo \& Abdul 2020).

The values of condition factor $>1$ indicate bonylip barb in lake Rawa Pening in good condition, sufficient feed available, and suitable habitat. Lake Rawa Pening obtains nutrients carried by surface streams and spring, which is very prolific (Samudra et al. 2013). This study's condition factor value was in line with the previous research in lake Rawa Pening (Rochmatin et al. 2014) and Temengor lake (Hamid et al. 2015). The highest factor value was found in adult fish populations or when habitat condi-tions were right, such as during the rainy season, which triggers an abundant prey population. Variations in length and weight size cause differences in the value of the condition factor.

Overall, the condition factor for female bonylip barb was higher than males. It shows that female was more efficient in utilizing feed sources. Also, in females, it was assumed that the proportion of ovarian weights to total body weight was more (Rochmatin et al. 2013). The ratio of female gonad weight ranges from 1.5$11.2 \%$, while males range from 1.2-5.0\% (Omar 2010). Young fish and dry season have undeveloped gonads, so the proportion of gonad weight to body weight was relatively low. Gonadal volume increases with the size and number of oocytes so that in adult individuals have a larger size and number of oocytes. Therefore, in the spawning season, which coincides with the rainy 
season, the stomach cavity was filled with more gonads, then the proportion of gonad weights was higher than in other seasons.

The condition factor of the male and female bonylip barb each month of sampling has the same pattern and varies. The value of the condition factor in female fish was $>1.05$ (very plump), while the male was between 0.95-1.05 (medium fat). The high fish condition factor occurs at the peak of the rainy season, while it is relatively low at the beginning or end of the rainy season. It indicates that the habitat of lake Rawa Pening can provide sufficient feed and nutrients so that it is suitable for the growth and reproduction of the bonylip barb. The lake Rawa Pening is very abundant in algae and aquatic plants (Goeltenboth \& Kristyanto 1994). Variations in the value of conditions related to season or rainfall. High rainfall brings many nutrients into the lake, thus stimulating the growth of phytoplankton and aquatic plants that can provide enough food for the bonylip barb.

\section{Conclusion}

Bonylip barb caught by blinds fishing gear in lake Rawa Pening has $10-26 \mathrm{~cm}$ and a weight of 15-265 g. The length and weight range of the female population was wider than the male. The length-weight relationship of bonylip barb was very strong and had a negative allometric pattern. Fish condition factors show that the female was very plump, and males were fat. Overall, female populations were more abundant than males and balanced at the peak rainy season.

\section{Acknowledgment}

Thank you to the Dean of the Agriculture Faculty UGM, who has funded the research grant no 1757/PT/PN/2019, and Mr. Arifin, who has helped collect samples of bonylip barb.

\section{References}

Aida SN, Utomo AD. 2016. Kajian kualitas perairan untuk perikanan di Rawa Pening, Jawa Tengah. Bawal. 8(3): 173-182.

Biswas SP. 1993. Manual Methods in Fish Biology. South Asian Publishers Pvt Ltd. New Dehli. India. 157 p.

Effendie MI. 2002. Biologi Perikanan. Yayasan Pustaka Nusatama. Cetakan Kedua. Yogyakarta. $163 \mathrm{hlm}$.

Froese R. 2006. Cube law, condition factor and weight-length relationships: history, metaanalysis and recommendations. Journal Applied Ichthyology, 22(1): 241-253.

Froese R, Pauly D. 2019. FishBase. World Wide Web electronic publication. www.fish base.org, (12/2019).

Famoofo OO, Abdul WO. 2020. Biometry, condition factors and length-weight relationships of sixteen fish species in Iwopin freshwater ecotype of Lekki Lagoon, Ogun State, Southwest Nigeria. Heliyon, 6(1): 1-8

Goeltenboth F, Kristyanto AIA. 1994. Fisheries in the Rawa Pening Reservoir, Java, Indonesia. International Review of Hydrobiology, 79(1): 113-129

Hamid MA, Mansor M, Nor SAM. 2015. Lengthweight relationship and condition factor of fish populations in Temengor Reservoir: Indication of environmental health. Sains Malaysiana, 44(1): 61-66.

Omar SBA. 2010. Aspek reproduksi ikan nilem, Osteochilus vittatus (Valenciennes, 1842) di Danau Sidenreng, Sulawesi Selatan. Jurnal Iktiologi Indonesia, 10(2): 111-122

Putri MRA, Sugianti YS, Krismono. 2015. Beberapa aspek biologi ikan nilem (Osteochillus vittatus) di Danau Talaga, Sulawesi Tengah. Bawal. 7 (2): 111-120

Radhi AM, Fazlinda MN, Amal MNA, Rohasliney H. 2018. A review of lengthweight relationships of freshwater fishes in Malaysia. Transylvanian Review of Systematical and Ecological Research, 20(1): 55-68. 
Rochmatin S Y, Solichin A, Saputra SW. 2014. Aspek pertumbuhan dan reproduksi ikan nilem (Osteochilus hasselti) di perairan Rawa Pening Kecamatan Tuntang Kabupaten Semarang. Diponegoro Journal of Maquares. 3(3): 153-159.

Rostika R, Andriani Y, Junianto. 2017. Fecundity performance of nilem (Osteochilus vittatus) from Cianjur, Tasikmalaya and Kuningan Districts, West Java, Indonesia. Asian Journal of Agriculture. 1(1): 17-21

Samudra SR, Soeprobowati TR, Izzati M. 2013. Komposisi, Kemelimpahan dan Keanekaragaman Fitoplankton Danau Rawa Pening Kabupaten Semarang. Bioma, 15(1): 6-13
Soetignya WP, Munir AMS, Hurriyani Y, Anzani YM. 2020. The reproductive biology of Waanders's hard-lipped barb, Osteochilus waandersii in the Landak River, Indonesia. AACL Bioflux, 13 (2): 640-649

Weri MN, Sucahyo. 2017. Keterkaitan alat tangkap ikan dengan jenis ikan yang didapatkan di Rawa Pening. Bioedukasi. 10(2): 35-43.

Zulfia, Aisyah N. 2013. Status trofik perairan rawa pening ditinjau dari kandungan unsur hara $\left(\mathrm{PO}_{3}\right.$ dan $\left.\mathrm{PO}_{4}\right)$ serta klorofil-a. Bawal, 5(3): 189-199. 
